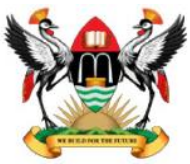

East African School of Higher Education Studies \& Development
Makerere Journal of Higher Education

ISSN: 1816-6822; 7 (2) (2015) 15 - 47

DOI: http://dx.doi.org/10.4314/majohe.v7i2.2

(C) The Author(s) 2015

Reprints \& permission: EASHESD

http://ajol.info/majohe

\title{
Framework for the Study of Employee Commitment
}

\author{
Wilson Mugizi ${ }^{1,}$, Fred E. K. Bakkabulindi ${ }^{1}$ *, Ronald Bisaso ${ }^{1}$ \\ ${ }^{1}$ Makerere University [* Corresponding author: fekbakkabulindi@cees.mak.ac.ug]
}

\begin{abstract}
This paper is a conceptual discussion of the construct of employee commitment identifying its antecedents in an organisational context. While the paper is of general interest to human resource management (HRM), it arose as part of a study on the commitment of academic staff in universities in Uganda. The paper suggests a framework for studying employee commitment, and proposes 21 hypotheses for future research basing on a review of recent literature. Each hypothesis suggests an antecedent. The antecedents are grouped into three categories, namely; HRM practices, organisational and personal characteristics. In terms of HRM practices, it is hypothesised that recruitment, selection, performance appraisal, promotion, participation, remuneration, job design, job security and grievances handling are antecedents of employee commitment. In regard to organisational characteristics, it is hypothesised that organisational structure, leadership styles, employee relationships and organisational support are antecedents of employ commitment. With personal characteristics, it is hypothesised that age, gender, educational level, marital status, job experience, job position and self-efficacy are antecedents of employee commitment. Gaps in the studies reviewed are identified.
\end{abstract}

Keywords: Employee Commitment; HRM Practices.

\section{$1 \quad$ Introduction}

Several attempts have been made to define "employee commitment." Perhaps the most comprehensive of those definitions is that of Meyer, Stanley and Parfyonova (2012) who define commitment using a multidimensional approach and consider it to have affective, continuance and normative perspectives. The affective dimension of commitment refers to an emotional attachment to and involvement with an organisation; continuance commitment denotes the perceived costs of leaving an organisation; and normative commitment refers to the felt responsibility to support and remain a member of an organisation. Thus it can be discerned from definitions such as the one above, that employee 
commitment is a bond between the employee and the organisation such that he/ she (the employee) wants to continue serving the organisation and to help it achieve its objectives.

The importance of "employee commitment" is well captured by different authors. Yilmaz and Çokluk-Bökeoğlu (2008) expound that employees with high organisational commitment feelings affect organisational performance in positive ways because they lessen the frequency of performing negative behaviour and improve quality of service. A committed employee is a more compatible and productive individual who has higher levels of satisfaction, loyalty and responsibility. They continue to observe that organisational commitment not only increases the success in a certain role, but also encourages the individual to achieve many voluntary actions necessary for organisational life and high standard system success.

Park, Christie and Sype (2014) advance that committed employees may be more likely to engage in organisational citizenship behaviours (OCBs), that is, extra-role behaviours, such as creativity or innovation which are often what keep organisations competitive. Creativity according to Bosiok and Sad (2013) is the ability to think in ways and forms that are new, different and not seen in other individuals. Other authors (e.g. Lambert \& Hogan, 2009) propose that employee commitment reduces employee turnover. Lambert and Hogan define employee turnover as the situation by which employees either voluntarily quit or are involuntarily terminated from their jobs. Allen, Bryant and Vardaman (2010) explain that with voluntary turnover, the employee initiates the quitting of the job; for example, quitting and taking another job while involuntary turnover is initiated by the organisation; for instance, when a company dismisses an employee due to poor performance or when there is organisational restructuring. Lambert and Hogan (2009) state that committed employees are loyal to the organisation, share its values, and identify with the goals of the organisation. Thus, they have little reason to want to leave.

On their part, Visagie and Steyn (2011) related employee commitment to acceptance of organisational change. Parnini (2011) define organisational change as an empirical observation in an organisational entity of variations in shape, quality or state over time, after the deliberate introduction of new ways of thinking, acting and operating. Visagie and Steyn explain that employee commitment to the organisation is critical when an organisation engages in change initiatives, as committed employees will provide many benefits to the organisation undergoing change. These benefits include putting in extra effort to ensure that the change succeeds, serving as public relations representatives during the change and going above and beyond the norm to assist the organisation to function effectively.

On the other hand, Demirel and Goc (2013) suggest that organisational commitment enhances knowledge sharing between employees. They define 
knowledge sharing as a process whereby an individual exchanges the knowledge he/ she possesses with other individuals for them to understand, appropriate and utilise that knowledge. Accordingly, with knowledge sharing, information, skill or expertise are reciprocally exchanged among people, friends, and members of family, community or organisation. They indicate that knowledge sharing is important in creation of new ideas among the employees and presenting new business ideas fundamental to a living organisation. Thus, modern organisations struggle to have workforce with sufficient knowledge and ability and survive in this struggle by creating efficient learning opportunities with efficient management. In summary, the various scholars above are unanimous to the effect that employee commitment is important in so far as enhancing employee job performance is concerned. This is because it lessens the frequency of employees performing negative behaviour; promotes employee's OCB, reduces employee turnover; makes the employees more ready to accept organisational change; and enhances knowledge sharing among the employees.

Given the importance of employee commitment (EC), one goal of research on EC is to identify its antecedents, which may in turn be manipulated to positively influence EC. In deriving the antecedents of EC, several theories can be considered. Of these theories, this paper was intended to review three of them, namely the Social Exchange Theory (SET), Leader-Member Exchange (LMX) Theory, and Social Identity Theory (SIT). The second objective of the paper was hence to build a conceptual framework relating EC to its antecedents, whereby the antecedents are classified as per the suggestions of the three theories. Third and lastly, the paper was intended to derive hypotheses from the framework to guide future research on the antecedents of EC.

\section{Theoretical Review}

Three theories are the basis for this paper, namely; the Social Exchange Theory, Leader-Member Exchange Theory and Social Identity Theory.

\subsection{Social Exchange Theory}

The Social Exchange Theory (SET) was developed by scholars such as Homans (1958) and Blau (1964) to explain what influenced social behaviour. Homans in an essay entitled "social behaviour" was interested in the psychological conditions that induce individuals to engage in exchange. Homans stated that social behaviour is an exchange of both material goods and non-material ones. Homans explained that persons that give much to others try to get much from them, and persons that get much from others are under pressure to give much to 
them. This process of influence tends to work out at equilibrium to balance the exchanges. In an exchange, what one gives may be a cost, just as what one gets may be a reward. Blau was interested in exchange as the elementary particle of social life, in which social structures are rooted. Blau analysed exchange processes as the micro-foundation of macro-sociological phenomena. Blau stated that mutual bonds emerge in social interaction as persons who incur obligations reciprocate. Marescaux, Winne and Sels (2013) explains that SET proposes that HRM practices initiate a positive exchange relationship to which employees reciprocate with positive attitudes and behaviour towards the organisation and/ or job.

Geetha and Mampilly (2012) argue that the basic principle with SET is that employees view satisfying HRM practices as an organisation's commitment towards them. Employees thus reciprocate this through positive behaviours like employee commitment. They are thus more likely to exchange their commitment for resources and benefits provided by their organisation. For example, when individuals receive economic and socio-emotional resources from their organisation they feel obliged to respond in kind and repay the organisation. SET argues that obligations generate through a series of interactions between parties who are in a state of reciprocal interdependence. The core belief in SET is that relationships evolve over time into trusting, loyal, and mutual commitments as long as the parties abide by certain "rules" of exchange. The rules of exchange usually involve reciprocity or repayment rules such that the actions of one party lead to a response or actions by the other party. Studies such as the study by Chew and Chan (2008) have SET as their theoretical basis. In summary, the propositions of SET indicate that social exchanges employees obtain from organisations such as HRM practices may lead to employee commitment.

\subsection{Leader-Member Exchange Theory}

The Leader-Member Exchange (LMX) theory was developed by Dansereau, Graen and Haga (1975) to describe the dyadic process by which roles and expectations are developed for a leader with each subordinate. They explained that approaching leadership as an exchange relationship which develops within the vertical dyad over time during role making activities leads to high exchange relationships. Accordingly, in the relationship, the degree of latitude a superior granted to a member to negotiate his/ her role is predictive of subsequent behaviour on the part of both superior and member. They expounded that in LMX, superiors employ both leadership and supervision techniques within their units. With a select subset of their members, superiors develop leadership exchanges (influence without authority), and with others, superiors develop only supervision relationships (influence based primarily upon authority). Yukl, 
O'Donnell and Taber (2009) indicate that The Leader-Member Exchange (LMX) propounds that high-exchange relationships characterise high-level of trust, liking, and respect (employer-employee relationships) and involve expectations of mutual exchange.

The leader provides outcomes desired by subordinates, such as interesting tasks, additional responsibilities, and larger rewards and the subordinates reciprocate with commitment to work and loyalty to the leader. In low-quality exchange relationships, subordinates only perform the formal requirements of their jobs, and the leader does not provide extra benefits. Exchange relationships develop gradually over time and reinforced by the behaviour of the leader and the subordinates. Studies such as the study by Eisenberger, Karagonlar, Stinglhamber, Neves, Becker, Gonzalez-Morales and SteigerMueller (2010) have used LMX as their theoretical basis. Overall, LMX proposes that organisational characteristics relate to employee commitment. In this paper, LMX is the basis for appraising organisational characteristics that relate to employee commitment.

\subsection{Social Identity Theory}

The Social Identity Theory (SIT) was advanced by Tajfel (1978) and Tajfel and Turner (1979) to explain the psychological basis for intergroup discrimination. Tajfel propounded that individuals assign emotional values to themselves based on their knowledge of themselves within groups and they compare their groups with other groups. On their part, Tajfel and Turner proposed that individuals concerned define themselves and are defined by others as members of a group. Accordingly, a collection of individuals who perceive themselves to be members of the same social category, share some emotional involvement in this common definition of themselves, and achieve some degree of social consensus about the evaluation of their group and of their membership of it. Boroş (2008) indicates that social identity was explained as that part of an individual's selfconcept which derives from one's knowledge of his/ her membership of a social group (or groups) together with the value and emotional significance attached to that membership.

According to Haslam, Jetten, Postmes and Haslam (2009), SIT proposes that our sense of who we are is enhanced by knowing not only that we belong to certain groups, but also that we are different from members of other groups. Jones and Volpe (2010) suggests that according to SIT individuals classify themselves and others into various social categories such as organisational membership, gender, race, age cohort, or religious affiliation and view their membership in particular groups based on social roles and role relationships. Previous studies such as Todd and Kent (2009) examined determinants of employee behaviour basing on SIT. Generally, SIT postulates that in 
organisations people classify themselves in social categories such as personal characteristics and this gives them identity leading to positives implications such as commitment. In this paper, this theory was the basis for relating personal characteristics on employee commitment.

\section{Conceptual Framework}

The review of the Social Exchange Theory (SET) brought out the fact that HRM practices initiate a positive exchange relationship to which employees reciprocate with positive attitudes and behaviour towards the organisation and/ or job (Marescaux et al, 2013). According to Geetha and Mampilly (2012), the basic principle with SET is that employees view satisfying HRM practices as an organisation's commitment towards them. Employees thus reciprocate this through positive behaviours like employee commitment. They are thus more likely to exchange their commitment for resources and benefits provided by their organisation. Hence, Figure 1 provides a framework of constructs as the first independent variable (IV1), namely; HRM practices that cause exchange relationship between employees and organisations leading to the dependent variable (DV) employee commitment. The HRM practices identified as the independent variables are namely recruitment, selection, job design, participation, performance appraisal, training, promotion and rewards (Burchielli, 2008), job security (Vlachos, 2009) and grievances handling (Zulkiflee, Faizal, Shakizah \& Durrishah, 2010).

On its part, the Leader-Member Exchange (LMX) propounds that highexchange relationships characterise high-level of trust, liking, and respect (employer-employee relationships) and involve expectations of mutual exchange. The leader provides outcomes desired by subordinates, such as interesting tasks, additional responsibilities, and larger rewards and the subordinates reciprocate with commitment to work and loyalty to the leader. Exchange relationships develop gradually over time and reinforced by the behaviour of the leader and the subordinates. This means that an organisation whose structure leads to assigning of employees different tasks and different responsibilities, a leadership style that offers rewards, creates good leadership and support employees will be reciprocated with commitment. Thus, Figure 1 contains a framework of constructs IV2, namely; organisational characteristics to which subordinates reciprocate with commitment which is the DV. Organisational characteristics pointed out are namely organisational structure, leadership styles, organisational relationships and organisational support (Nguyen, 2011).

Regarding the Social Identity Theory (SIT), it suggests that our sense of who we are is enhanced by knowing not only that we belong to certain groups, but also that we are different from members of other groups. According to 
Jones and Volpe (2010), SIT proposes that individuals classify themselves and others into various social categories and view their membership in particular groups based on social roles and relationships. This means that individuals categorise themselves according to individual characteristics, IV3 which gives them identity leading to positives implications such as commitment (IV3). Personal characteristics identified are namely, age, gender, educational level, marital status, job experience, job position and self-efficacy (Suman \& Srivastava, 2012). The following sections present a derivation of 21 hypotheses based on the conceptual framework (Figure 1).

Independent variables

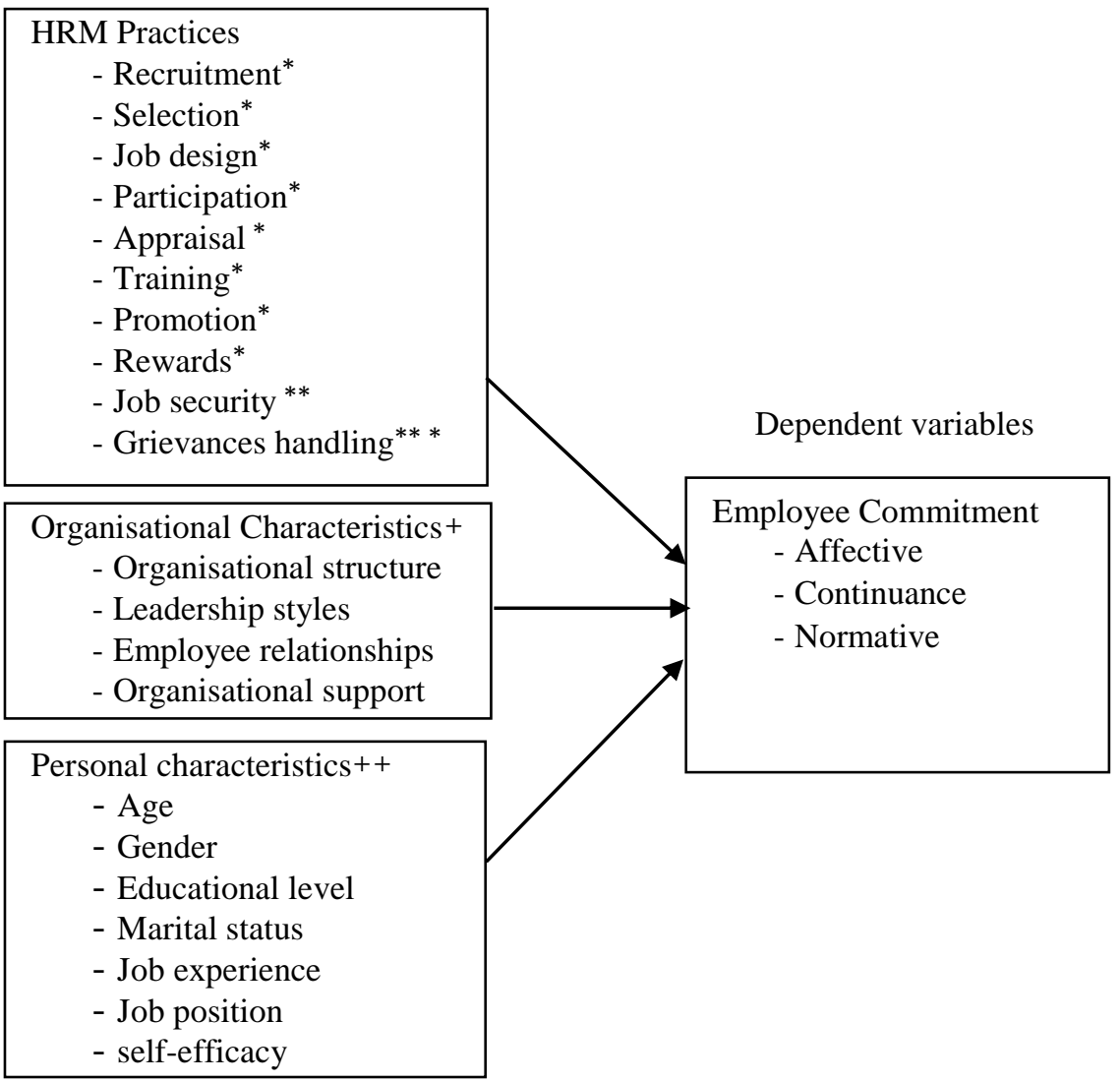

Figure 1: Conceptual Framework.

Sources: Adapted from *Burchielli (2008); ${ }^{* *}$ Vlachos (2009); ${ }^{* * *}$ Zulkiflee et al. (2010); + Nguyen (2011); ++Suman and Srivastava (2012); $\ddagger$ Meyer et al. (2012). 
HRM Practices as Antecedents of Employee Commitment

\subsection{Recruitment as an Antecedent of Employee Commitment}

Georgia, George and Labros (2013) define recruitment as the searching for and obtaining potential job candidates in sufficient numbers and quality so that the organisation can select the most appropriate people to fill its job needs. Hassink and Russo (2008) explain that employees' relationship with the organisation commences with the recruitment process. The initial schemas that employees have when they begin the recruitment process will influence their job attitude on being hired. Accordingly, the recruitment process may be partly responsible for job fit or mismatch. When expectations and contributions of each party (employees and the organisation) match what each of them had expected, stronger employment relationships follow. On the other hand, unmet expectations are associated with lower employment relationships (Aggarwal \& Bhargava, 2009). In his submission, Campbell (2010) posits that literature on organisational referrals as a hiring source shows the significance of recruitment in promoting employee behaviour. Job candidates referred by an organisation's current workers tend to have better post-hire career outcomes.

The reason for this is that the referrer effectively screens the applicant based on superior information to that which the organisation would not have in the absence of referral, thus providing a more appropriate match for the organisation. Consequently, the selected employee will be a committed one because of proper job match fit. Several recent studies (e.g. Chew \& Chan, 2008; Edwards \& Billsberry, 2010; Gutierrez, Candela \& Carver, 2012) positively related recruitment to employee commitment. However, as the above studies suggest, many earlier studies have been carried out in the context of the western world such as the Australia (e.g. Chew \& Chan, 2008) and the United States of America (e.g. Edwards \& Billsberry, 2010; Gutierrez et al., 2012). This contextual gap calls for further research on the relationship between the HRM practice of recruitment and employee commitment in other contexts such as the developing countries.

\subsection{Employee Selection as an Antecedent of Employee Commitment}

Selection is the process of assessing the suitability of candidates by predicting the extent to which they will be able to carry out a role successfully (Armstrong, 2010). Armstrong explains that this involves deciding on the degree to which the characteristics of applicants in terms of their competencies, experience, qualifications, education and training match the person specification. Georgia et al. (2013) suggest that the initial step in selection is 
to categorise candidates as probable, possible or unsuitable. Apparently, this is done by comparing the information provided in the application form or curriculum vitae against pre-determined selection criteria. Potentially suitable candidates will only proceed with the selection process. Accordingly, once the number of shortlisted applicants have been identified and invited, the process of in-depth assessment can begin with an extensive range of assessment methods such as interviews, psychological tests and assessment centres to identify competent candidates that meet the employer's candidate profile and fit the organisation culture.

Scheible and Bastos (2012) posit that personnel selection may contribute to the affective and normative commitments to the organisation because by selecting the best available candidates, pride is built in them stimulating them to keep their promises to the organisation. There are recent researches (e.g. De Cooman, Gieter, Pepermans, Hermans, Du Bois, Caers \& Jegers, 2009; Harold \& Shiju, 2012; Obeidat, Masa'deh \& Abdallah, 2014) demonstrating that selection positively related to employee commitment. However, contextual gaps emerge from those studies, in that many of the studies were done on the Western World (De Cooman et al. 2009) and Asia (Harold \& Shiju, 2012; Obeidat et al., 2014). Further research should be carried out on the relationship between selection and employee commitment in other contexts such as Africa.

\subsection{Job design as an Antecedent of Employee Commitment}

Job design, sometimes also referred to as job redesign, refers to any set of activities that involve the alteration of specific jobs or interdependent systems of jobs with the intent of improving the quality of employee job experience and their on-the-job productivity (Maxwell, 2008). Three common approaches to job design are namely; job rotation, enrichment and enlargement (Maxwell, 2008). Job rotation is the performing of a variety of production tasks on different job assignments on a scheduled basis (Angelis, Conti, Cooper \& Gill, 2010). Angelis et al. posit that job rotation increases the scope of production duties, thus it can be seen as trust in the ability of workers to multi-task. Job enrichment, according to Maxwell (2008), involves an increase in the level of responsibility for planning and coordinating tasks, sometimes referred to as vertical loading. This changes the employee's day-to-day job or increases the individual's participation in decisions affecting his or her work. Job enrichment allows vertical expansion, which increases the depth of the organisation and gives employees greater responsibility. The added responsibility increases the independence and the self-assessment leading to benefits for the organisation such as less absenteeism and less turnover which are indicators of commitment. Job enlargement, Maxwell (2008) expounds, is the putting of more variety into 
a worker's job by combining specialised tasks of comparable difficulty, a process also known as horizontal loading.

This makes the job more appealing and rewarding allowing employees to identify their contributions to the overall production of products and goods. According to Truss et al. (2013), people whose jobs are varied are more likely to experience a sense of energy in relation to their work because monotonous work can lead to psychological distress. Multi-tasked work makes people autonomous making them experience a feeling of responsibility and are more likely to invest effort into their work, even in the face of obstacles. A person who is responsible for a whole piece of meaningful work (identity) and perceives his/ her work as significant is more likely to invest his/ her whole self into their work and experience a sense of pride. There are recent studies (e.g. Angelis et al., 2010; Boselie, 2010; Wang, Indridason \& Saunders, 2010) that positively related job design to employee commitment. However the cited studies suggest a skew of the studies towards the developed world such as the United Kingdom (e.g. Angelis et al, 2010; Wang et al., 2010) and the Netherlands (e.g. Boselie, 2010). Therefore, future research relating the two variables should be on other geographical contexts.

\subsection{Employee Participation as an Antecedent of Employee Commitment}

Employee participation means the entrance of employees into the authority and operations of management. It involves employees having the opportunity to influence of decision-making throughout the organisation (Busck, Knudsen \& Lind, 2010). Busck et al. explain that with employee participation, the employer, voluntarily or by compulsion, yields power of decision to the employees or to their representatives. This may occur in the form of joint decisions (e.g. pay and working hours agreed in collective bargaining), decision-making based on consultation with employees (e.g. in works councils or at workshop level), or decision making left by the employer to the employees themselves (delegation of decision authority, autonomous teams or selfmanagement).

Busck et al. (2010) indicate that participation in addition to increased productivity through commitment, leads to greater responsibility and avoidance of conflicts in connection with changes, and contributes to a higher degree of well-being at work through motivation and empowerment. Recent studies (e.g. Angelis et al., 2010; Appelbaum, Louis, Makarenko, Saluja, Meleshko \& Kulbashian, 2013; Elele and Fields, 2010; Henkin \& Holliman, 2008) positively correlating participation and employee commitment are available. However those studies suggest a bias of earlier studies towards the developed world such as Canada (Appelbaum et al., 2013); the United Kingdom (e.g. 
Angelis et al, 2010) and the United States (e.g. Henkin \& Holliman, 2008). Hence the need for future studies to deal with other contexts also.

\subsection{Training as an Antecedent of Employee Commitment}

Training refers to a systematic approach to learning and development to improve individual, team and organisational effectiveness (Aguinis \& Kraiger, 2009). Training involves the application of formal processes to impart knowledge and help people to acquire the skills necessary for them to perform their jobs satisfactorily (Armstrong, 2010). Employee training serves a variety of purposes, including, but not limited to, leadership development, learning new work skills, socialisation encompassed in orienting new employees to the culture of an organisation, understanding job responsibilities and educating employees in regard to business ethics (Schraeder, 2009).

Gellatly, Hunter, Currie and Irving (2009) indicate that HRM practices aimed at building employee capabilities (e.g., skill training) increase feelings of internal control (autonomy) and competence, which, in turn, increase one's identification, involvement, and emotional connection with the work and the organisation as an individual and the organisation as a whole. Recent empirical studies positively relating training and employee commitment include Mohyin, Dainty and Carrillo (2012); Savaneviciene and Stankeviciute (2011) and Truitt (2011). All the above studies however, were carried out in the context of the Western World, namely the UK (Mohyin et al., 2012), the USA (Truitt, 2011) and Lithuania (Savaneviciene \& Stankeviciute, 2011). This contextual gap leaves the question of whether training influences employee commitment in other contexts such as in sub Saharan Africa.

\subsection{Performance Appraisal as an Antecedent of Employee Commitment}

Performance appraisal (PA) is the systematic evaluation of an employee with regard to his or her performance on the job and his potential for development (Toppo \& Prusty, 2012). Armstrong (2010) states that appraisal is an opportunity to take an overall view of work content, loads and volumes, to look back at what has been achieved during the reporting period and agree on objectives for the next period. Manoharan, Muralidharan and Deshmukh (2012) indicate that in general, PA is concerned with the assessment of three areas, namely results, behaviours, and personal characteristics. Prowse and Prowse (2009) contend that performance appraisal provides a major potential for employee feedback that links strongly to increasing motivation, an opportunity to clarify goals and achieve long-term individual performance and career development. 
Trivellas (2009) argue that appraisal provides feedback guidance in the context of an effective and more complete system of performance management which fosters employee motivation contributing to increased commitment. Recent studies offering insight on the relationship between performance appraisal and employee commitment (e.g. Farndale, Hope-Hailey \& Kelliher, 2011; Kuvaas, 2010; Morrow, 2011) can be pointed out. However, some gaps still emerge at contextual and methodological levels. At contextual level, the studies by Kuvaas (2010) and Farndale et al. (2011) were carried out in Norway and UK respectively, and at methodological level, the study by Morrow (2011) was a review of previous studies. Therefore, there is need for further empirical studies to be carried out and in other contexts such as those of developing countries of Africa particularly.

\subsection{Promotion as an Antecedent of Employee Commitment}

Promotion refers to an increase in job responsibility, scope, authority, or level within or outside the organisation (Singh, Ragins \& Tharenou, 2009). Pfeifer, Janssen, Yang and Backes-Gellner (2011) indicate that promotions are important from the point of view of both employer and employee because the employees benefit from promotions by monetary gains and higher reputation, whereas employers can use promotions to make efficient job assignments. Several recent studies (e.g. Gunlu, Aksarayli \& Percin, 2010; McCabe \& Garavan, 2008; Scheible \& Bastos, 2013) have positively related promotion to employee commitment. However, most of the studies above were carried out in the context of the Western World (e.g. Gunlu et al., 2010; McCabe \& Garavan, 2008) and the Caribbean (Scheible \& Bastos, 2013). Besides they were carried out in the context of an information technology company (Scheible \& Bastos, 2013), health service (McCabe \& Garavan, 2008) and hotel industry (Gunlu et al., 2010). Future research can be carried out in the developing world of Africa and in other contexts such as universities.

\subsection{Rewards as an Antecedent of Employee Commitment}

Rewards are benefits that arise from performing a task, rendering a service or discharging a responsibility (Agwu, 2013). Nujjoo and Meyer (2012) indicate that classic categorisation of rewards distinguishes them as intrinsic and extrinsic. They define intrinsic rewards to denote satisfaction that a person derives from doing the job. Stumpf, Tymon Jr, Favorito and Smith (2013) expound that intrinsic rewards are based on employees getting a positively valued experience from doing their work such as experience of work as meaningful, the ability to exercise some degree of choice, the experience of progress and the development of a greater sense of competence. Ganzach and 
Fried (2012) consider extrinsic rewards to refer to valuable goals which are external to the job itself that provide satisfaction to individuals (i.e., the extrinsic rewards provide the means to support the goals of the self and family members, such as living in a nice neighbourhood, providing the children with a good education, etc.). Extrinsic rewards include pay, job security, supervisor and peers support among others.

Pratheepkanth (2011) indicates that an intrinsically motivated individual will be committed to his/ her work to the extent to which the job inherently contains tasks that are rewarding to him/her and an extrinsically motivated person will be committed to the extent that he/ she can gain or receive external rewards for his or her job. In all, for an individual to be motivated in a work situation there must be a need, which the individual would have to perceive a possibility of satisfying through some reward. Recent studies (e.g. Gellatly, Hunter, Currie \& Irving, 2009; Mohyin et al., 2012; Tornikoski, 2011) revealed the importance of rewards in promoting employee commitment, although they raise contextual gaps. That is, all the above studies were carried out in the Western World with the study by Tornikoski (2011) carried out in Finland, while the study by Gellatly et al. (2009) was carried out in Canada and Mohyin et al. (2012) in the UK. Future research can thus be carried out in other contexts such as those of the developing countries.

\subsection{Job Security as an Antecedent of Employee Commitment}

Job security can be conceptualised at two levels: job security in terms of keeping the job and safety in terms of employee well-being. Stander and Rothmann (2010) define job security as the perceived stability and continuance of one's job. On the other hand, Armstrong (2010) indicates that safety deals with the prevention of accidents and minimising the resulting loss and damage to persons and property. Noble (2008) explains that within the classic Maslow's hierarchy of needs, the notions of safety, security and protection occupy the second tier of the model, suggesting that they are even more sophisticated needs than the fundamental physiological concerns. He argues that job security fears can lead to several negative consequences, including decreased satisfaction and a greater propensity to leave one's job. By perceiving insecurity about the job on the part of the employee, the psychological contract, that is, the agreement between the organisation and an employee about their beliefs regarding the terms of employment (Peene, 2009).

In other words, the perceived mutual obligations between employer and employee may be perceived as violated by the organisation; employees depend on the organisation so they lose faith in the dependability of the organisation. As a result, the commitment of an employee towards the organisation may decrease. Previous studies in the recent past (e.g. Bayona-Sáez, Goñi-Legaz \& 
Madorrán-García, 2009; Chen, Myrtle, Liu \& Fahey, 2011; Ünsal-Akbıyık, Çakmak-Otluoğlu \& De Witte, 2012) relate job security to employee commitment. However, controversies emerge from the above studies which present a research gap. Whereas, studies by Chen et al. (2011) and ÜnsalAkbiyık et al., (2012) indicated positive significant association between job security and employee commitment, Bayona-Sáez et al. (2009) found insignificant association. Future researchers can therefore, further appraise the relationship between job security and employee commitment.

\subsection{Grievance handling as an Antecedent of Employee Commitment}

Grievance handling or management is all about how well problems between employees and management are addressed in organisations. Grievances of employees relate contracts, work rules or regulations, policies or procedures, health and safety regulations, past practices, changing the cultural norms unilaterally, individual victimisation and wages and bonuses among others (Gomathi, 2014). When a conflict is not dealt with effectively, it may lead to a breakdown in team interaction, causing errors and poor performance. Chronic unresolved conflicts increase the rate of employee turnover in organisations and affect people and relationships other than those initially affected such as external stakeholders (customers) and investors (Zuwena, 2014). Thus effective grievance handling is an essential part of cultivating good employee relations and running a fair, successful and productive workplace (Gomathi, 2014).

Several recent researchers (e.g. Harney \& Jordan, 2008; Harold \& Shiju, 2012; Polster, 2011) have related grievance handling and employee commitment. Whereas, the above empirical studies made effort to link grievances handling and employee commitment, controversial results that lead to a gap for further research emerge. For instance, whereas the studies by Harney and Jordan (2008) and Harold and Shiju (2012) found out that grievance handling significantly related to employee commitment, Polster (2011) indicated that formal grievance procedures had the unintended consequence of increasing employees' commitment to their complaints and exacerbating workplace conflicts. Therefore, this controversy calls for further research on the relationship between grievances handling and employee commitment. 


\section{Organisational Characteristics as Antecedents of Employee Commitment}

\subsection{Organisational Structure as an Antecedent of Employee Commitment}

Organisational structure refers to both the communication lines and the reporting responsibilities in an institution (Holtzhausen \& Fourie, 2011). Ashworth, Boyne and Delbridge (2009) define organisational structure as the set of rules and roles that shape the relationships between parts of an organization. Lunenburg (2012) explains that the term organisational structure covers the formal configuration between individuals and groups regarding the allocation of tasks, responsibilities and authority within the organisation. Suman and Srivastava (2012) indicate that aspects of an organisational structure are size, work rules and policy (formalisation), roles, number of levels in the organisational hierarchy and the extent of flatness or centralisation. They explain that with centralisation there is an increase of decision making at the higher hierarchical levels within an organisation and a decrease of participation of employees in the decision making process. Flatness is the degree to which an organisation has minimal levels of management hierarchy. However, specialised structures have departments with employees that are functionally specialised or integrated. Low levels of horizontal integration reflect an organisation in which the departments and employees are functionally specialised, whereas high levels of horizontal integration reflect an organisation in which departments and employees are integrated in their work, skills, and training.

They contend that a decision-making organisational structure that encourages member participation or a communication process which keeps the individual informed with respect to valued aspects of the organisation may affect felt responsibility and role involvement and therefore, commitment. Recent studies on organisational structure and employee commitment include the studies by Harney and Jordan (2008); Sahoo, Behera and Tripathy (2010) and Suman and Srivastava (2012). However, from the above studies some gaps emerge. For example, whereas, Harney and Jordan (2008) established that flat structures did not motivate employee commitment, Suman and Srivastava (2012) in a study in India and Sahoo et al. (2010) in systematic review of the previous research works established a positive relationship between organisational structure and employee commitment. Besides, Harney and Jordan (2008) carried out their study in the UK and Suman and Srivastava (2012) carried out their study in India. The controversy in the findings of the studies above and contextual gaps call for further research on organisational structure as an antecedent of 
employee commitment in other contexts such as the developing countries of Africa.

\subsection{Leadership Styles as Antecedent an of Employee Commitment}

Leadership is the process by which an individual influences a group of individuals to achieve a common goal (Cummings, MacGregor, Davey, Lee, Wong, Lo, Muise \& Stafford, 2009). Cheok and O'Higgins (2012) contend that a leadership style that encourages employee involvement can help to satisfy employees' desire for empowerment and demand for a commitment to organisational goals. They explain that a more flexible and participatory leadership style can strongly and positively enhance organisational commitment. On the other hand, Wong (2012) states that leadership styles that are relational in nature are associated with organisational commitment and a leadership that provides hope, trust, positive emotions and optimism influences employees' commitment.

There are recent studies that related leadership styles with employee commitment (e.g. Bambacas \& Patrickson, 2008; Dunn, Dastoor \& Sim, 2012; Mendelson, Turner \& Barling, 2011). However, although the studies above attempted to relate leadership styles and employee commitment, gaps still emerge at contextual and empirical level. At the contextual level at the above studies were carried out in the Western World. At the empirical level, the study by Dunn et al. (2012) raises controversy as its findings ascertained that for employees from the US the transformational leadership practice of inspiring the vision correlated with employee commitment, but this was not so in Israel. This thus calls for further study on the constructs in other contexts such as the developing countries of Africa.

\subsection{Employee Relationships as Antecedents of Employee Commitment}

Employee relations refer to connection between employees with the organisation and with each other and include the processes of developing, implementing, administering and analysing the employer - employee relationship, managing employee performance and resolving work place conflicts/ disputes (Sundaray, Sahoo \& Tripathy, 2010). Leat (2008) summarises that employee good relations are responsible for the notion of psychological contract that is an implicit contractual relationship which is derived from a series of assumptions on the part of employer and employee about the nature of their relationship. These assumptions may not be legally enforceable but they constitute a set of reciprocal arrangements and form the basis for a series of expectations that may have a considerable degree of moral force. The main assumptions are that: employees will be treated fairly and 
honestly; the relationship will be characterised by a concern for equity and justice and this will require the communication of sufficient information about changes and developments.

Employee loyalty to the employer will be reciprocated with a degree of employment and job security; and employees' input will be recognised and valued by the employer. Studies relating relationships and employee commitment can be found (e.g. Caykoylu, Egri, Havlovic \& Bradley, 2011; Brunetto, Farr-Wharton \& Shacklock, 2010; Martín, 2008). The studies above attempted to relate relationships and employee commitment although some gaps remain at contextual level. The contexts of the above studies was the Western World and in the medical sector (Brunetto et al., 2010; Caykoylu et al., 2011) and business enterprises (Martín, 2008). This calls for future research on the relationship between employee-employer relations in the context of the developing countries and in other sectors such as education.

\subsection{Organisational support as an Antecedent of Employee Commitment}

Lew (2011) notes that organisational support concerns discretionary practices which the organisation is not obligated to offer that imply organisational caring and commitment towards the wellbeing of the employees but not made compulsory by company policy, union contract or laws of the country (for example, career development opportunities and work/family support) and second, organisational recognition for the employee's contribution (e.g. pay satisfaction). Accordingly, employees interpret organisational support as indicative of commitment to them by the organisation's high level of caring and concern. In return, employees will reciprocate this kind deed by increasing their own commitment to the organisation by being highly involved in the organisation and showing their willingness to work hard to accomplish the organisation's goals (Lew, 2011).

Recent empirical studies (e.g. Colakoglu, Culha \& Atay, 2010; Maurer \& Lippstreu, 2008; Wang et al., 2010) can be cited. However, whereas some studies (e.g. Colakoglu et al., 2010; Wang et al., 2010) established a significant relationship between support and employee commitment, other studies (e.g. Maurer \& Lippstreu, 2008) established that support for employee development had less impact on commitment if the employees were focused on trying to prove their current skills and competence to others. Therefore, future research should grapple with establishing how organisational support affects various categories of employees in organisations differently. 


\section{Personal Characteristics as Antecedents of Employee Commitment}

\subsection{Age as an Antecedent of Employee Commitment}

Age refers to an individuals' number of years. For purposes of a given study, age can be categorised for identification, in which case people may belong to different age group, such as young, middle-aged and old. On average, people generally stop being described as young at approximately 40 years of age (Abrams, Vauclair \& Swift, 2011). Age represents the evolutions taking place in people's life over time, in terms of biological, psychological and social functioning (Innocenti, Profili \& Sammarra, 2013). Thus, age is related with affective and normative occupational commitment because the age of an individual in terms of affective commitment is an indicator of them getting a better position in the organisation or profession and gaining tenure (Benligiray \& Sonmez, 2013). As for the normative commitment, age is an indicator of the investments an individual has made in his/ her organisation or profession.

In the recent past several scholars (e.g. Angelis et al., 2010; Dick, 2011; Innocenti et al, 2013) have related age to employee commitment. However, in the studies above there are some contextual and empirical gaps that call for further studies. At contextual level, the studies were carried out in the Western World and in assembling industries (Angelis et al., 2010), Police (Dick, 2011) and industrial and service sectors (Innocenti et al., 2013). At empirical level, whereas Dick (2011) found out that age had a small influence on organisational commitment, Angelis et al. (2010) and Innocenti et al (2013) suggested that age was positively related to employee commitment. This thus calls for further empirical research and in other contexts such as the developing world of Africa.

\subsection{Gender as an Antecedent of Employee Commitment}

Gender can be defined from the cultural or role perspectives. Defined from the cultural perspective, gender refers to the social classification of an individual as either masculine or feminine (Snowdon, 2009). In terms of roles, gender is a variable distinguishing women and men as individuals or as defining relationships located within the context of the family (Ferree, 2010). In research, gender-sensitive data are those compiled and analysed while recognising that gender-based factors influence women's and men's different social conditions, relations and access to resources (Sanga, 2008). Khalili and Asmawi (2012) indicate that gender has been considered in organisational commitment literature from two aspects: the job model and the gender model.

The job model approach indicates that there are no differences in the work attitudes of males and females; and work attitudes of men and women extended 
in similar ways. On the contrary, the gender model in the study of organisational commitment and females indicates that women accept family roles as a chief source of their identity and fulfilment leading to a different orientation to work from that of men for whom work is paramount. Studies in the recent past (e.g. Bayona-Sáez et al., 2009; Dick, 2011; Giffords, 2009) examined gender and employee commitment. All the above studies were unanimous that gender had a weak correlation with employee commitment. However, all the above studies were carried out in the context of the Western World. Future research should explore the relationship between gender and employee commitment in the context of developing countries.

\subsection{Educational Level and Employee Commitment}

Education is the measure of knowledge and skills (Barton, Armstrong, Preheim, Gelmon \& Andrus, 2009). Thomas and Feldman (2009) indicate that education level which is also known as qualifications refers to the academic credentials an individual obtains. According to Sutherland (2012), qualifications constitute a measure of educational attainment and academic competence. Thomas and Feldman (2009) state that most organisations use education level as an indicator of a person's skill levels or productivity and that it is frequently employed as a prerequisite in hiring decisions. They explain that individuals with more education are likely to have greater in-depth, analytical knowledge (crystallised intelligence) as well. Khan, Khan, Khan, Nawaz and Yar (2013) suggest that qualifications play a leading role in the development of organisational commitment because as the qualifications of individuals get better, their sense of belongingness is improved. They add that when institutions employ a qualified workforce then their performance and productivity will be marvellous in direct proportion.

However, Jafri (2011) states that educational qualification is a negative predictor of commitment because people with higher qualifications want to grow professionally and economically, they expect more and in search of the fulfilment of this need, they keep on moving or they want to move where they find opportunities better. He indicates that the other reason may be that many options are available for qualified and skilled persons and that is why they keep on moving to get diverse exposure and better opportunities. Prior studies in the recent past (e.g. Bayona-Sáez et al., 2009; Benligiray \& Sonmez, 2013; Innocenti et al., 2013) related education levels to employee commitment. However, from the studies above, some gaps emerge. For instance, the studies by Benligiray and Sonmez (2013) related education to continuance commitment, the studies Innocenti et al. (2013) and Bayona-Sáez et al. (2009) related it to affective commitment. Besides, all the above studies used a quantitative approach and were carried out in western world. Therefore, future 
research should further investigate the relationship between education and all the three aspects of commitment, namely; affective, continuance and normative using a qualitative and in other the contexts such as the developing countries of Africa.

\subsection{Marital Status as an Antecedent of Employee Commitment}

Marital status is the state of being married or unmarried, and involves being married/ cohabitating, never married/ living alone, divorced/ living alone, and widow/ widower/ living alone. Regarding the relationship between marital status and employee commitment, Benligiray and Sonmez (2013) assert that marital status negatively affects occupational and career commitments because the time and energy needed to keep a marriage stable has a negative effect on work life and occupational commitment. They explain that working couples have difficulties in making arrangements for their children and career responsibilities. However, Bayona-Sáez et al. (2009) suggest otherwise indicating that marital status enhances employee commitment.

This is because marital status increases workers' family responsibilities which make employees with family responsibilities more reliant (continuance commitment) on the organisation to fulfil their financial needs. Recent past studies (e.g. Bayona-Sáez et al., 2009) that empirically found marital status and employee commitment to be related can be found. But so are others (Cohen \& Veled-Hecht, 2010; Gurses \& Demiray, 2009) that did not. Further, many of the studies (e.g. Bayona-Sáez et al., 2009; Cohen \& Veled-Hecht, 2010; Gurses \& Demiray, 2009) based only on quantitative surveys and were carried out in the Western World. Therefore, there is need for more empirical studies using other approaches such as the qualitative approach for in-depth analysis especially in the context of developing countries.

\subsection{Job Experience as an Antecedent of Employee Commitment}

Job experience also known as employee tenure means the length of time an individual employee has worked for an organisation and represents the accumulation of specialised organisationally relevant knowledge and information (Gilson, Lim, Luciano \& Choi, 2013). Bhopatkar (2013) indicates that during this period the employee learns as well as relearns working, evinces many things, faces different aspects of work, earns seniority and proceeds to maturity that reflects the mental enhancement of a person amassed by endeavouring different actions in life. Accordingly, the different situations or occurrences broaden the mind-set of the employee that aids his/ her decisionmaking. Experiences offer different phases of learning process which are narrow initially, but with the passing of time, the learning process enhances the 
mental power and reaches the stage where an emotionally stable and logical individual develops. Bayona-Sáez et al. (2009) argue that older employees may have received more rewards from the organisations and besides they may justify their long service to the organisation by deciding they like it (affective commitment). Shore, Bommer and Shore (2009) contend that employees with long organisational tenure may be tied to their organisation because of the high costs of leaving (e.g. pension benefits and seniority) and non-portable training.

The accumulation of these investments over time is believed to make living difficult and to increase continuance commitment. Employees with greater sunk costs such as long tenure will remain with their organisation due to high continuance commitment. A number of recent studies have related experience and employee commitment (e.g. Benligiray \& Sonmez, 2013; Dick, 2011; Karakus \& Aslan, 2009). However, the studies above which were carried out in Europe leave some unanswered gaps. Whereas Dick (2011) found that Police constables with more than 20 years' service demonstrated higher levels commitment, Karakus and Aslan (2009) established that teachers who had served for more than 21 years were the least affectively committed. Thus the issue of age as a correlate of employee commitment is controversial. Still, Benligiray and Sonmez (2013) found a negative correlation between tenure and occupational commitment. These controversies besides differences in sectors from which samples were drawn, that were police (Dick, 2011), teachers (Karakus \& Aslan, 2009) and nurses (Benligiray \& Sonmez, 2013) call for further research on experience in other sectors.

\subsection{Job status as an Antecedent of Employee Commitment}

Job status refers to the position that an employee occupies in the workplace. They indicate that in every organisation, there is a hierarchy among the employees that is based on position, title, role, and function and job positions can be categorised as top, middle and bottom. Olapegba and Onuoha (2013) contend that job position influences job commitment with those in senior position being more committed than those in subordinate positions because of benefits and perks of office enjoyed by those in senior positions. Higher ranking personnel receive higher pay, have better opportunities and benefits (such as overseas trips, housing allowance), less job risks and occupational hazards. The leadership role increases the feeling of having a higher stake in the organisation which in turn increases the level of job commitment of those in senior positions. The importance of job status in relation to employee commitment can be understood from the context of the Side-Bet Theory propounded by Becker in 1960. Wood and Rowe (2011) indicate that side-bets are investments accumulated that are valued by the individual which would be lost if he or she were to leave the organisation. 
The Side-Bet Theory postulates that individuals often do not base decisions, such as job or career changes purely on economic conditions but rather they are influenced or constrained by investments made in the organisation which make them committed to stay. Therefore, an individual considering a new job opportunity may be deterred because the move may cost the person their seniority, job status implied. Several recent studies demonstrate that job status positively correlate with employee commitment (Dick, 2011; Shore et al., 2008; Turunen, 2011). However, the studies above were carried out in the context of the Western World and with Police Officers (Dick, 2011) and employees in manufacturing industries (Shore et al., 2008) as units of analysis. Future research should be carried out in the context of the developing countries and in other sectors.

\subsection{Self-Efficacy as an Antecedent of Employee Commitment}

Self-efficacy is the people's judgment of their capabilities to organise and execute courses of action required to attain designated types of performances (Van Vuuren, de Jong \& Seydel, 2008). Zulkosky (2009) describes selfefficacy as the difference in how people feel, think, behave, and are motivated. In terms of feeling, a low sense of self-efficacy is associated with stress, depression, anxiety, and helplessness. Individuals with a low sense of self efficacy have low self-esteem and are pessimistic about their accomplishments and personal development. In terms of thinking, a strong sense of efficacy facilitates cognitive processes and performance in a variety of settings, including quality of decision making and academic achievement. People with high self-efficacy approach difficult tasks as challenges and do not try to avoid them. People's self-efficacy beliefs determine their level of motivation, as reflected in how much effort they will exert in an endeavour and how long they will persevere in the face of obstacles. Van Vuuren et al. (2008) contend that unless people believe that their actions can produce the outcomes they desire, they have little incentive to act or to persevere in the face of difficulties. Thus, self-efficacy beliefs affect virtually every aspect of People's lives including organisational commitment.

Zulkosky (2009) state that people with high levels of self-efficacy are more likely to set higher goals, commit to challenges that are more difficult, and strive to meet those goals because human behaviour is regulated by forethought embodying cognised goals, and personal goal setting is influenced by selfappraisal of capabilities. Individuals with high self-efficacy achieve their goals by visualising successful outcomes instead of dwelling on the potential negative consequences. A major function of thought is to enable people to predict the occurrence of events and to create the means for exercising control over those that affect their daily lives. This leads to their commitment to organisations. 
Recent studies pertaining self-efficacy and employee commitment (e.g. Bayona-Sáez et al., 2009; Canrinus, Helms-Lorenz, Beijaard, Buitink \& Hofman, 2012; Suman \& Srivastava, 2012) reported the existence of a positive relationship. However, the context of the studies above was the Western World (Bayona-Sáez et al., 2009; Canrinus et al., 2012) and Asia (Suman \& Srivastava, 2012). This contextual gap calls for further research in the context of African countries.

\section{$7 \quad$ Conclusion}

This paper reviewed literature on employee commitment at conceptual, theoretical and empirical levels. The paper was divided into seven sections. In section 1, the definition of employee commitment is given, stressing its nature as a multi-dimensional construct made up of the three perspectives of affective, continuance and normative commitment. In the same section, the importance of employee commitment is discussed, pointing out its capacity to enhance employee job performance. This is because it lessens the frequency of employees performing negative behaviour; promotes employee's OCB, reduces employee turnover; makes the employees more ready to accept organisational change; and enhances knowledge sharing among the employees.

In section 2, three theories (Socio Exchange, Leader-Member Exchange and Socio identity) relating employee commitment to its antecedents were reviewed. In the third section a framework relating employee commitment to three categories of antecedents was suggested. In sections 4 through 6 , hypotheses for future research relating individual antecedents to employee commitment are derived via a literature review, before a conclusion is given in this section. In the empirical literature reviewed, it was identified that most studies relating to employee commitment have been done in the western world and a few others in Asia. Thus other developing countries especially Africa has been left unexplored as far as the variable is concerned. This is food for thought for future researchers.

\section{References}

Abrams, D., Vauclair, M., \& Swift, H. S. (2011). Predictors of attitudes to age across Europe. Department for Work and Pensions Research Report No 735. Retrieved from: http://research.dwp.gov.uk/asd/asd5/rrs-index.asp.

Aggarwal, U., \& Bhargava, S. (2009). Reviewing the relationship between human resource practices and psychological contract and their impact on 
employee attitude and behaviours. Journal of European Industrial Training, 33(1), 4-31. doi: 10.1108/0309059 0910924351

Aguinis, M., \& Kraiger, K. (2009). Benefits of training and development for individuals and teams, organisations, and society. Annual Review of Psychology, 60, 45-474. doi: 10.1 146/annurev.psych.60.110707.163505

Agwu, M. O. (2013). Impact of fair reward system on employees' job performance in Nigerian Agip Oil Company Limited Port-Harcourt. British Journal of Education, Society \& Behavioural Science, 3(1), 47-64

Allen, D. G., Bryant, P. C., \& Vardaman, J. M. (2010). Retaining talent: Replacing misconceptions with evidence-based strategies. The Academy of Management Perspectives, 24(2), 48-64.

Angelis, J., Conti, R., Cooper, C., \& Gill, C. (2010). Building a highcommitment lean culture. Journal of Manufacturing Technology Management, 22(5), 569-586. doi: 10.1108/17410381111134446

Appelbaum, S. H., Louis, D., Makarenko, D., Saluja, J., Meleshko, O., \& Kulbashian, S. (2013). Participation in decision making: A case study of job satisfaction and commitment. Industrial and Commercial Training, 45(4), 222-229. doi: 10.1108/00197851311323510

Armstrong. M. (2010). Armstrong's essential human resource management practice: A guide to people management. London, UK: Kogan Page Limited. Ashworth, R., Boyne, G., \& Delbridge, R. (2009). Escape from the iron cage? Organisational change and isomorphic pressures in the public sector. Journal of Public Administration Research and Theory, 19(1), 165-187. doi: 10.1093/jopart/mum038

Bambacas, M., \& Patrickson, M. (2008). Interpersonal communication skills that enhance organisational commitment. Journal of Communication Management, 12(1), 51-72. doi: 10.1108/13632540810854235

Barton, A. J., Armstrong, G., Preheim, G., Gelmon, S. B., \& Andrus, L. C. (2009). A national delphi to determine developmental progression of quality and safety competencies in nursing education. Nursing Outlook, 57(6), 313322. doi: 10.1016/j.outlook.2009.08.003

Bayona-Sáez, C., Goñi-Legaz, S., \& Madorrán-García, C. (2009). How to raise commitment in public university lecturers. International Review of Administrative Sciences, 75(2), 333-347. doi: 10.1177/0020852309104179

Benligiray, S., \& Sonmez, H. (2013). The analysis of demographic and work life variables which affect the occupational commitment of nurses. Journal of Management Development, 32(4), 419-434. doi: $10.1108 / 02621711311326392$

Bhopatkar, N. (2013). Effect of emotional intelligence and job tenure on employee effectiveness. MERCGlobal's International Journal of Management, 1(2), 86-102.

Blau, P. M. (1964). Exchange and power in social life. New York, USA: Wiley. 
Boroş, S. (2008). Organisational identification: Theoretical and empirical analyses of competing conceptualisations. Cognition, Brain, Behaviour, 12(1), 1-27.

Boselie, P. (2010). High performance work practices in the health care sector: A Dutch case study. International Journal of Manpower, 31(1), 42 - 58. doi: 10.1108/01437721011031685

Bosiok, D., \& Sad, N. (2013). Leadership styles and creativity. Online Journal of Applied Knowledge Management, 1(2), 64 - 77.

Brunetto, Y., Farr-Wharton, R., \& Shacklock, K. (2010). The impact of supervisor-subordinate relationships on morale: Implications for public and private sector nurses' commitment. Human Resource Management Journal, 20(2), 206-225. doi: org/10.1111/j.1748-8583.20 09.00117.x.

Burchielli, R. (2008). Human resource management practices in trade unions: Implications for strategy. Asia Pacific Journal of Human Resources, 46(1), 56-67. doi: 10.1177/103841 1107082279.

Busck, O., Knudsen, H., \& Lind, J. (2010). The transformation of employee participation: Consequences for the work environment. Economic and Industrial Democracy, 31(3), 285-305. doi: 10.1177/0143831X0935121

Campbell, D. (2010, August). Employee selection as a control system. Harvard Business School Working Paper 11-021.

Canrinus, E. T., Helms-Lorenz, M., Beijaard, D., Buitink, J., \& Hofman, A. (2012). Self-efficacy, job satisfaction, motivation and commitment: Exploring the relationships between indicators of teachers' professional identity. European Journal Psychology Education, 27, 115-132. doi 10.1007/s10212-011-0069-2.

Caykoylu, S., Egri, P., Havlovic, S., \& Bradley, C. (2011). Key organisational commitment antecedents for nurses, paramedical professionals and nonclinical staff. Journal of Health Organisation and Management, 25(1), 7-33.

Chen, D., Myrtle, R., Liu, C., \& Fahey, D. (2011). Job and career influences on the career commitment of health care executives: The mediating effect of job satisfaction. Journal of Health Organisation and Management, 25(6), 693710.

Cheok, S. L., \& O'Higgins, E. R. E. (2012). Enhancing employee outcomes: The interrelated influences of managers' emotional intelligence and leadership style. Leadership and Organisation Development Journal, 33(2), 149-174. doi: 10.1108/01437731211203465

Chew, J., \& Chan, C. C. A. (2008). Human resource practices, organisational commitment and intention to stay. International Journal of Manpower, 29(6), 503-522.

Cohen, A., \& Veled-Hecht, A. (2010). The relationship between organisational socialisation and commitment in the workplace among employees in long- 
term nursing care facilities. Personnel Review, 39(5), 537-556. doi: 10.1108/00483481011064136

Colakoglu, U., Culha, O., \& Atay, H. (2010). The effects of perceived organisational support on employees' affective outcomes: Evidence from the hotel industry. Tourism and Hospitality Management, 16(2), 125-150.

Cummings, G. G., MacGregor, T., Davey, M., Wong, C. A., Lo, E., Muise, M., \& Stafford, E. (2009). Leadership styles and outcome patterns for the nursing workforce and work environment: A systematic review. International Journal of Nursing Studies, 47(3), 363-385. doi: 10.1016/j.jinurstu.2009.08.006

Dansereau, F., Graen, G., \& Haga, W. J. (1975). A vertical dyad linkage approach to leadership within formal organisations: A longitudinal investigation of the role making process. Organisational Behaviour and Human Performance, 13(1), 46-78. doi: org/10.1016/00 30-5073(75)900057

De Cooman, R., Gieter, S. D., Pepermans, R., Hermans, S., Du Bois, C, Caers, R., \& Jegers, M. (2009). Person-organisation fit: Testing socialisation and attraction-selection-attrition hypotheses. Journal of Vocational Behaviour, 74(1), 102-107. doi: 10.1016/j.jvb.2008.1 0.010

Demirel, Y., \& Goc, K. (2013). The impact of organisational commitment on knowledge sharing. European Scientific Journal, 9(19), 945-963.

Dick, G. P. (2011). The influence of managerial and job variables on organisational commitment in the Police. Public Administration, 89(2), 557576. doi: 10.1111/j.1467-9299.2010.01 874.x

Dunn, M. W., Dastoor, B., \& Sim, R. L. (2012). Transformational leadership and organisational commitment: A cross-cultural perspective. Journal of Multi-Disciplinary Research, 4(1), 45-59

Edwards, J. A., \& Billsberry, J. (2010). Testing a multidimensional theory of person-environment fit. Journal of Managerial Issues, 22(4), 476-493.

Eisenberger, R., Karagonlar, G., Stinglhamber, F., Neves, P., Becker, T. E., Gonzalez-Morales, M. G., \& Steiger-Mueller, M. (2010). Leader-member exchange and affective organisational commitment: The contribution of supervisor's organisational embodiment. Journal of Applied Psychology. doi: $10.1037 / \mathrm{a} 0020858$

Elele, J., \& Fields, D. (2010). Participative decision making and organisational commitment comparing Nigerian and American employees. Cross Cultural Management: An International Journal, 17(4), 368-392. doi: $10.1108 / 13527601011086586$

Farndale, E., Hope-Hailey, V., \& Kelliher, C. (2010). High commitment performance management: The role of justice and trust. Personnel Review, $40(1), 5-23$. 
Ferree, M. M. (2010). Filling the glass: Gender perspectives on families. Journal of Marriage and Family, 72, 420-439: doi 10.1111/j.17413737.2010.00711.x

Ganzach, Y., \& Fried, I. (2012). The role of intelligence in the formation of well-being: From job rewards to job satisfaction. Intelligence, 40(4), 333342. doi:10.1016/j.intell.2012.03.004

Geetha, J., \& Mampilly, S. R. (2012). Satisfaction with HR practices and employee engagement: A social exchange perspective. Journal of Economics and Behavioural Studies, 4 (7), 423-430.

Gellatly, I. R., Hunter, K. H., Currie, L. G., \& Irving, P. G. (2009). HRM practices and organisational commitment profiles. The International Journal of Human Resource Management, 20(4), 869-884. doi: 10.1080/09585190902770794

Georgia, A., George, A., \& Labros, S. (2013). Employee recruitment and selection in the insurance sector: The case of the Greek insurance group. European Journal of Management Sciences, 1(1), 1-20.

Giffords, E. D. (2009). An examination of organisational commitment and professional commitment and the relationship to work environment, demographic and organisational factors. Journal of Social Work, 9(4), 386404. doi: $10.1177 / 1468017309346232$

Gilson, L. L., Lim, H. S., Luciano, M. M., \& Choi, J. N. (2013). Unpacking the cross-level effects of tenure diversity, explicit knowledge, and knowledge sharing on individual creativity. Journal of Occupational and Organisational Psychology, 86(2), 203-222. doi: 10.1111/joop.12011

Gomathi, S. (2014). A study on grievance management in improving employee performance in a private enterprise. Mediterranean Journal of Social Sciences, 5(20), 20-29. doi: 10.5901/ mjss.2014.v5n20p20

Gunlu, E., Aksarayli, M., \& Percin, N. S. (2010). Job satisfaction and organisational commitment of hotel managers in Turkey. International Journal of Contemporary Hospitality Management, 22(5), 693-717.

Gurses, N \& Demiray, E. (2009). Organisational commitment of employees of a TV production centre (Educational Television ETV) for open education facility, Anadolu University. The Turkish Online Journal of Educational Technology 8(1). Retrieved from: files.eric.ed.gov/fulltext/ED503902.pdf.

Gutierrez A. P., Candela L. L., \& Carver, L. (2012). The structural relationships between organisational commitment, global job satisfaction, developmental experiences, work values, organisational support, and person-organisation fit among nursing faculty. Journal of Advanced Nursing 68(7), 1601-1614. doi: 10.1111/j.1365-2648.2012.05990.x

Harney, B., \& Jordan, C. (2008). Unlocking the black box: Line managers and HRM-Performance in a call centre context. International Journal of Productivity and Performance Management, 57(4), 275-296. 
Harold, A. P., \& Shiju, S. (2012). Human resources management practices' influence on faculty commitment in higher educational institutions. Asian Journal of Management Research, 3(1), 125-138.

Haslam, A., Jetten, J., Postmes, P., \& Haslam, C. (2009). Social identity, health and well-being: An emerging agenda for applied psychology. Applied Psychology: An International Review, 58(1), 1-23.

Hassink, W., \& Russo, G. (2008). Wage differences between internal and external candidates. International Journal of Manpower, 29(8), 715 -730. doi: 10.1108/01437720810919314

Henkin, A. B., \& Holliman, S. L. (2008). Urban teacher commitment exploring associations with organisational conflict, support for innovation, and participation. Urban Education, 44(2), 160-18. doi: 10.1177/0042085907312548

Holtzhausen, L., \& Fourie, L. (2011). Employees' perceptions of institutional values and employer-employee relationships at the North-West University. Journal of Public Affairs, 11(4), 243-254. doi: 10.1002/pa.417

Homans, G. C. (1958). Social behaviour as exchange. American Journal of Sociology, 63(6), 597-606.

Innocenti, L., Profili, S., \& Sammarra, A. (2013). Age as moderator in the relationship between HR development practices and employees' positive attitudes. Personnel Review, 42(6), 724-744. doi: 10.1108/PR-Jan-2012-0009

Jafri, M.H. (2011, June). A study on relationship of personal attributes organisational commitment and work performance. Paper presented in 1st International Conference on Business Strategy \& Management in Kolkatta.

Jones, C., \& Volpe, E. H. (2011). Organisational identification: Extending our understanding of social identities through social networks. Journal of Organisational Behaviour, 32(3), 413-434.

Karakus, M., \& Aslan, B. (2009). Teachers' commitment focuses: A threedimensioned view. Journal of Management Development, 28(5), 425-438. doi 10.1108/02621710910955967

Khalili, A \& Asmawi, A. (2012). Appraising the impact of gender differences on organisational commitment: Empirical evidence from a private SME in Iran. International Journal of Business and Management, 7(5), 100-110. doi: org/10.5539/ijbm.v7n5p100

Khan, I., Khan, F., Khan, H., Nawaz, A., \& Yar, N. B. (2013). Determining the demographic impacts on the organisational commitment of academicians in the HEIs of DCs like Pakistan. European Journal of Sustainable Development, 2(4), 117-30.

Kuvaas, B. (2010). The interactive role of performance appraisal reactions and regular feedback. Journal of Managerial Psychology, 26(2), 123-137. doi: $10.1108 / 02683941111102164$ 
Lambert, E., \& Hogan, N. (2009). The importance of job satisfaction and organisational commitment in shaping turnover intent a test of a causal model. Criminal Justice Review, 34(1), 96-118.

Leat, M. (2008). Employee relations. Edinburgh, UK: Edinburgh Business School.

Lew, T. Y. (2011). Affective organisational commitment and turnover intention of academics in Malaysia. 2010 International Conference on Business and Economics Research, IACSIT Press, Kuala Lumpur, Malaysia.

Lunenburg, F. C. (2012). Organisational Structure: Mintzberg's framework. International Journal of Scholarly, Academic, Intellectual Diversity, 14(1), $1-8$.

Manoharan, T. R., Muralidharan, C., \& Deshmukh, S. G. (2012). A composite model for employees' performance appraisal and improvement. European Journal of Training and Development, 36(4), 448-480. doi: 10.1108/03090591211220366

Marescaux, E., De Winne, S., \& Sels, L. (2013). HR practices and HRM outcomes: The role of basic need satisfaction. Personnel Review, 42(1), 4-27. doi: $10.1108 / 00483481311285200$

Martín, S. S. (2008). Relational and economic antecedents of organisational commitment. Personnel Review, 37(6), 589-608. doi: 10.1108/00483480810906856

Maurer, T. J., \& Lippstreu, M. (2008). Who will be committed to an organisation that provides support for employee development? Journal of Management Development, 27(3), 328-347. doi: 10.1108/02621710810858632

Maxwell, J. R. (2008). Work system design to improve the economic performance of the firm. Business Process Management Journal, 14(3), 432446. doi: 10.1108/1463715081087 6715.

McCabe, T. J \& Garavan, T. N. (2008). A study of the drivers of commitment amongst nurses; The salience of training, development and career issues. Journal of European Industrial Training, 32(7), 528-568. doi: 10.1108/03090590810899829.

Mendelson, M. B., Turner, N., \& Barling, G. (2011). Perceptions of the presence and effectiveness of high involvement work systems and their relationship to employee attitudes: A test of competing models. Personnel Review, 40(1), 45-69. doi: 10.1108/00483481111095519

Meyer, J. P., Stanley, L. J., \& Parfyonova, N. M. (2012). Employee commitment in context: The nature and implication of commitment profiles. Journal of Vocational Behaviour,80(1), 1-16. doi: 10.1016/j.jvb.2011.07.002.

Mohyin, N.A., Dainty, A. R. J., \& Carrillo, P. M. (2012, July). HRM strategies for managing employee commitment: A case study of small construction 
professional services firms. Working paper proceedings engineering project organisations conference Rheden, The Netherlands.

Morrow, P. C. (2011). Managing organisational commitment: Insights from longitudinal research. Journal of Vocational Behaviour, 79(1), 18-35. doi: 10.1016/j.jvb.2010.12.008.

Nguyen, L. D. (2011). Organisational characteristics and employee overall satisfaction: A comparison of state-owned and non-state owned enterprises in Vietnam. The South East Asian Journal of Management, 5(2), 135-153.

Noble, C. H. (2008). The influence of job security on field sales manager satisfaction: Exploring frontline tensions. Journal of Personal Selling \& Sales Management, 28(3), 247-261. doi: 10.2753/PSS0885-3134280303.

Nujjoo, A., \& Meyer, I. (2012). The relative importance of different types of rewards for employee motivation and commitment in South Africa. South African Journal of Human Resource Management, 10(2), 1-10. doi: org/10.4102/sajhrm.v10i2.442.

Obeidat, B. Y., Masa'deh, R., \& Abdallah, A. B. (2014). The relationships among human resource management practices, organisational commitment and knowledge management processes: A structural equation modelling approach. International Journal of Business and Management, 9(3), 9-26. doi: org/10.5539/ijbm.v9n3p9.

Olapegba, P. O., \& Onuoha, U. C. (2013). Personality attributes and personal characteristics affecting job commitment of officers and men of Nigeria Police Force. European Scientific Journal, 9(32), 1857-7881

Park, H. Y., Christie, R. L., \& Sype, G. E. (2014). Organisational commitment and turnover intention in union and non union firms. Sage Open. doi: 10.1177/215824401 3518928.

Parnini, S. N. (2011). The role of government in economic development: A comparative study between Bangladesh and South Korea. Journal of Public Administration and Governance, 1(1), 197-341. doi: 10.5296/jpag.v1i1.742.

Peene, N. (2009). Occupational commitment as a moderating variable insecure times: Job insecurity and its consequences on organisational commitment. Tilburg University Human Resource Studies. Retrieved from: arno.uvt.nl/show.cgi?fid=97367.

Pfeifer, C., Janssen, S., Yang, P., \& Backes-Gellner, U. (2011). Effects of training on employee suggestions and promotions in an internal labour market. IZA Discussion Paper No. 5671.

Polster, J. C. (2011). Workplace grievance procedures: Signalling fairness but escalating commitment. The New York Urban League Review, 86, 638-672.

Pratheepkanth, P. (2011). Reward system and its impact on employee motivation in commercial bank of Sri Lanka Plc, in Jaffna District. Global Journal of Management and Business Research, 11(4), 84-94. 
Prowse, P., \& Prowse, J. (2009). The dilemma of performance appraisal. Measuring Business Excellence, 13(4), 69-77. doi: 10.1108/13683040911006800.

Sahoo, C. K., Behera, N \& Tripathy, S. K. (2010). Employee empowerment and individual commitment: An analysis from integrative review of research. Employment Relations Record, 10(1), 40-55.

Sanga, D. (2008). Addressing gender issues through the production and use of gender-sensitive information. The African Statistical Journal, 7, 101-124.

Savaneviciene, A., \& Stankeviciute, Z. (2011). Human resource management practices linkage with organisational commitment and job satisfaction. Economics and Management, 17(1), 390-396.

Scheible, A. C. F., \& Bastos, A. V. B. (2013). An examination of human resource management practices' influence on organisational commitment and entrenchment. BAR, Rio de Janeiro, 10(1), 57-76.

Schraeder, M. (2009). Leveraging potential benefits of augmentation in employee training. Industrial and Commercial Training, 41(3), 133-138. doi: 10.1108/00197850910950916.

Singh, R., Ragins, B. R., \& Tharenou, P. (2009). Who gets a mentor? A longitudinal assessment of the rising star hypothesis. Journal of Vocational Behaviour, 74(1), 11-17. doi: 10.101 6/ j.jvb.2008.09.009.

Shore, T. H., Bommer, W. H., \& Shore, L. M. (2008). An integrative model of managerial perceptions of employee commitment: Antecedents and influences on employee treatment. Journal of Organisational Behaviour, 29(5), 635-655. doi: 1 0.1002/job.516.

Snowdon, R. (2009). Gender trouble: Coming to terms with postmodern feminist approaches. The School of Historical Studies Postgraduate Forum E-Journal,

Edition

7. Retrieved from: Dostupné z: $<$ http://www.societies.ncl.ac.uk/shspgf/ed_6. ht>.

Stander, M. W., \& Rothmann, S. (2010). Psychological empowerment, job insecurity and employee engagement. Southern Africa Journal of Industrial Psychology, 36(1), 1-8. doi: 10.4102/sajip.v36i1.849.

Stumpf, S. A., Tymon Jr, W. G., Favorito, N., \& Smith, R. R. (2013). Employees and change initiatives: Intrinsic rewards and feeling valued. Journal of Business Strategy, 34(2), 21-29. doi: $10.1108 / 02756661311310422$.

Suman, S., \& Srivastava, A. K. (2012). Antecedents of organisational commitment across hierarchical levels. Psychology and Developing Societies, 24(1), 61-83. doi: 10.1177/09 7133361102400103.

Sundaray, B. K., Sahoo, C. K., \& Tripathy, S. K. (2010, December). Employee relations initiatives and quality of work life: A study in power sector units. In 
52nd Annual Conference of the Indian Society of Labour Economics, Karnataka University, Dharwad.

Sutherland, J. (2012). Qualifications mismatch and skills mismatch. Education and Training, 54(7), 619-632. doi: 10.1108/00400911211265666.

Tajfel, H. (1978). Social categorisation, social identity, and social comparison. In H. Tajfel (Ed.). Differentiation between social groups: Studies in the social psychology of intergroup relations (pp. 61-76). London, UK: Academic Press.

Tajfel, H., \& Turner, J. (1979). An Integrative Theory of Intergroup Conflict. In S. Worchel, \& W. Austin (Eds.), The social psychology of intergroup relations. Monterey, CA, USA: Brooks/ Cole.

Thomas, W. H., \&. Feldman, D. C. (2009). How broadly does education contribute to job performance? Personnel Psychology, 62, 89-134.

Todd, S., \& Kent, A. (2009). A social identity perspective on the job attitudes of employees in sport. Management Decision, 47(1), 173 - 190.

Toppo, L., \& Prusty, T. (2012). From performance appraisal to performance management. IOSR Journal of Business and Management (IOSRJBM), 3(5), $1-6$.

Tornikoski, C. (2011). Fostering expatriate affective commitment: A total reward perspective. Cross Cultural Management: An International Journal, 18(2), 214-235. doi: 10.1108/13527601111126030.

Trivellas, P. (2009, May). Impact of strategic human resource management on organisational commitment and employee satisfaction in ISO 9001 certified firms: An empirical study in Central Greece. 6th International Conference on Enterprise Systems, Accounting and Logistics (6th ICESAL '09), Thessaloniki, Greece.

Truitt, D. L. (2011). The effect of training and development on employee attitude as it relates to training and work proficiency. SAGE Open. doi: $10.1177 / 2158244011433338$.

Truss, K., Baron, A., Crawford, D., Debenham, T., Emmott, M., Harding, S. Totterdill, P. (2013). Job design and employee engagement. An 'Engage for Success' white paper. Retrieved from: www.engageforsuccess.org/.../JobDesign-and-Employee-Engagement.

Turunen, T. (2011). Commitment to employment and organisation: Finland in a European Comparison. Research on Finnish Society, 4, 55-66.

Ünsal-Akbıyık, B. S., Çakmak-Otluoğlu, K. O and De Witte, H. (2012). Job insecurity and affective commitment in seasonal versus permanent workers. International Journal of Humanities and Social Science, 2(24), 14-20.

Van Vuuren, M., de Jong, M. D. T., \& Seydel, E. R. (2008). Contributions of self and organisational efficacy expectations to commitment: A fourfold typology. Employee Relations, 30(2), 142-155. doi: $10.1108 / 01425450810843339$. 
Visagie, C. M., \& Steyn, C. (2011). Organisational commitment and responses to planned organisational change: An exploratory study. Southern African Business Review, 15(3), 98-121.

Vlachos, I. P. (2009). The effects of human resource practices on firm growth. International Journal of Business Science and Applied Management, 4(2), 17-34.

Wang, C. L., Indridason, T., \& Saunders, N. K. (2010). Affective and continuance commitment in public private partnership. Employee Relations, 32(4), 396-417. doi: 10.1108/01425 451011051613.

Wong, C. A. (2012). Advancing a positive leadership orientation: From problem to possibility. Nursing Leadership, 25(2), 51-55. doi: 10.12927/cjnl.2012.22961.

Wood, M. S., \& Rowe, J. D. (2011). Entrapment as an unintended consequence of entrepreneurial success. Frontiers of Entrepreneurship Research, 31(6), 240-254.

Yilmaz, K., \& Çokluk-Bökeoğlu, Ö. (2008). Organisational citizenship behaviours and organisational commitment in Turkish primary schools. World Applied Sciences Journal, 3(5), 775-780.

Yukl, G., O'Donnell, M., \& Taber, T. (2009). Influence of leader behaviours on the leader-member exchange relationship. Journal of Managerial Psychology, 24(4), 289-299.

Zulkiflee, D., Faizal, B. M. I., Shakizah, W. M. N., \& Durrishah, B. I. (2010). Grievance handling style among heads of department at a telecommunication company in Malaysia. International Conference on Business and Economic Research. Retrieved from: www. internationalconference.com.my/.../PAPER 211 GrievanceHandli.

Zulkosky, K. (2009). Self-efficacy: A concept analysis. Nursing Forum, 44(2) 93-102.

Zuwena, P. (2014). Best practice grievance handling: Exploring its importance to the internal/external customer satisfaction equation at a Caribbean University. Journalism and Mass Communication, 4(2), 101-124. 